\title{
Extractable Soil Nitrogen Following Clear-cutting and Burning in a Beech Forest ${ }^{\mathbf{1}}$
}

\author{
M. J. Phillips AND K. M. GoH ${ }^{2}$
}

\begin{abstract}
Nitrogen (N) mineralization was monitored in the humus layer and soil in an undisturbed and harvested beech (Nothofagus) spp. forest in the West Coast of the South Island of New Zealand. To assess the effects of different harvesting regimes and intensities of burning on $\mathbf{N}$ mineralization, treatments applied were (i) Podocarpus spp. clear-cutting; (ii) Podocarpus spp. clear-cutting and prescribed burning; (iii) harvesting to chipwood standard (10-cm dbh); and (iv) chipwood logging and prescribed burning. Nitrate was found to be negligible in fresh and field-incubated humus and soil samples in the undisturbed beech forest. Ammonium predominated in both the humus layer and soil. Clear-cutting, and clear-cutting and burning increased $\mathrm{NH}_{4}^{+}-\mathrm{N}$. The burning effect was confined mainly to the humus layer.
\end{abstract}

Additional Index Words: harvesting regimes, burning intensities, $\mathrm{N}$ cycling, $\mathrm{NO}_{3}^{-}, \mathrm{NH}_{4}^{+}$, field incubated soil samples, humus layer, Nothofagus spp.

Phillips, M.J., and K.M. Goh. 1985. Extractable soil nitrogen following clear-cutting and burning in a beech forest. Soil Sci. Soc. Am. J. 49:1563-1568.

\section{MATERIALS AND METHODS}

\section{Study Site}

The Larry's Creek study area $\left(42^{\circ} 20^{\prime} \mathrm{S}, 171^{\circ} 50^{\prime} \mathrm{E}\right)$ was located $30-\mathrm{km}$ north of Reefton on the West Coast of the South Island of New Zealand. The site was on remnants of a terrace that has been truncated and dissected into undulating topography. The elevation was $200 \mathrm{~m}$ on a south-west aspect with slopes avg $18 \%$. Rainfall averaged approximately $1800-\mathrm{mm}$ annually. Many terraces have been formed as a consequence of regional tectonic uplift and subsequent river incision. The oldest have been dissected further by streams. Our site was underlain by weakly to moderately weathered gravels containing clasts of granites, schists, sandstones, and siltstones. These were underlain by Cenozoic siltstone and sandstone. Four major soil classes were identified as: Yellow Brown earth (Inceptisol), Gley soil (Aquept); Humic Gley with thin Fe pan (Placiaquept); and Podzol (Spodic soil).

Approximately $95 \%$ of the forest cover was silver beech ( $N$. menziesil) and red beech ( $N$. fusca). Remaining species were predominantly podocarps mostly kahikatea (Podocarpus dacrydioides), miro ( $P$. ferrugineus), matai ( $P$. specatus), and rimu (Dacrydium cupressinum).

\section{Experimental Design}

\section{Treatments}

Harvesting treatments were applied in a completely randomized block design, consisting of three replications of high intensity burn, low intensity burn, and nonburning treatments. High intensity burns were obtained by burning the residues (e.g., leaves, branches, twigs, stems, litter) from clearcutting followed by harvesting only podocarp species (PL/B). Low intensity burns were obtained by burning the

\footnotetext{
${ }^{1}$ Contribution from Dep. of Soil Science, Lincoln College, Canterbury, New Zealand. Received 21 Sept. 1984. Approved 6 June 1985.

2 Postgraduate Student and Reader, respectively, Lincoln College, New Zealand. Present address of Dr. Phillips: Soil Science Dep. Univ. of Florida, Gainesville, FL 32611.
}

residues from logging (i.e., materials $<10-\mathrm{cm} \mathrm{dbh}$ ) after harvesting to chipwood standard $(10-\mathrm{cm} \mathrm{dbh})(\mathrm{CL} / \mathrm{B})$ treatments. Control nonburning treatments on each block consisted of podocarp logged (PL) and chipwood logged (CL) treatments. Each block contained four 0.08-ha plots with treatments assigned randomly within the block in a transect line running across the midslope. Also, one forested plot $(F)$ was established $20-\mathrm{m}$ above each of the major blocks. The plots were harvested in May 1976. All designated plots were burned in February 1977, and radiata pine seedlings were planted in July 1977.

\section{Measurements}

The field method for measuring soil $\mathrm{N}$ mineralization was based on the method described by Ellis (1974). Instead of using plastic vials, 4.0 -cm diam nylon cloth tubes $(0.045-$ $\mathrm{mm}$ aperture) were used for incubating litters and soil samples in the field. This allowed the free drainage of soil water which prevented water logging and anaerobic conditions. The nylon tubes also allowed better contact between the incubated core samples and the surrounding soil. Due to the free drainage of water, however, an unmeasured portion of the mineralized $\mathrm{N}$ was probably leached. Mineralized $\mathrm{N}$ was measured in the humus layer and at two soil depths (0-9 $\mathrm{cm}, 9-18 \mathrm{~cm}$ ).

Four field fresh and incubated samples were obtained at each depth from random locations in each plot during each sampling period. To obtain each fresh sample and prepare one field incubated sample, individual soil cores were taken with a tubular probe (diam $4.0 \mathrm{~cm}$ ). Litter or ash was first removed, then each core was divided into the different depths and placed separately into plastic bags and mixed. Visible plant roots and stones were removed. Each composite sample was divided into two; one for field incubation and the other as the fresh sample for analysis in the laboratory with no further incubation. This procedure was repeated for the other three cores.

To prepare for field incubation soil from the composite sample taken from the $9-$ to $18-\mathrm{cm}$ soil depth was placed in the nylon tube and packed to a length of $9 \mathrm{~cm}$. A constriction in the nylon tube was then made. The process was repeated for soil from the $0-$ to $9-\mathrm{cm}$ depth. The remaining length of the tube $(5-8 \mathrm{~cm})$ was filled with the humus sample. The filled tube was placed into one of the sample collection holes and covered with approximately $4 \mathrm{~cm}$ of litter or ash. All samples were stored on ice for transportation to the laboratory. Field sampling began $1 \mathrm{~d}$ before burning (February 1977 ) and continued for 1 yr (February 1978). For the first $35 \mathrm{~d}$ after burning, samples were obtained at intervals of 3 , 10,11 , and $14 \mathrm{~d}$. Further samples were tisen collected at 30to 60 -d intervals.

Humus and soil $(<2 \mathrm{~mm})$ samples were extracted with 2 $M \mathrm{KCl}$ for $2 \mathrm{~h}$ on a shaker. An extractant/sample ratio of $10.1(\mathrm{w} / \mathrm{w})$ was used. Extracts were filtered through Whatman no. 32 paper. Ammonium $N$ was determined by the phenol-hypochlorite method (Weatherburn, 1967). This method was compared with $\mathrm{NH}_{4}^{+}-\mathrm{N}$ determination by steam distillation. Results agreed closely between the methods, which indicated that the $2 \mathrm{M} \mathrm{KCl}$ was not extracting significant amounts of free amino acid $N$. Nitrate $N$ was first reduced to $\mathrm{NO}_{2}^{-}$by passing through a $\mathrm{Cd}$ column reductor and determined by Grasshoff's (1969) method. Results for $\mathrm{NH}_{4}^{+}-\mathrm{N}$ and $\mathrm{NO}_{3}^{-}-\mathrm{N}$ are expressed on an oven-dry basis. The amount of $\mathrm{N}$ mineralized between sampling periods was determined as the difference in exchangeable $\mathrm{N}$ between the incubated and fresh samples. Pretreatment differences in 
Table 1. Nitrate-N concentration in humus and soil $(0-9,9-18 \mathrm{~cm})$ in the standing beech forest and in the clearcut and clearcut logged/burned plots from 1977 to 1978.

\begin{tabular}{|c|c|c|c|c|c|c|c|c|c|c|}
\hline \multirow[b]{3}{*}{ Layer } & \multicolumn{10}{|c|}{ Treatment } \\
\hline & \multicolumn{2}{|c|}{$\mathbf{F}$} & \multicolumn{2}{|c|}{ CL } & \multicolumn{2}{|c|}{$\mathbf{C L} / \mathrm{B}$} & \multicolumn{2}{|c|}{$\mathbf{P}$} & \multicolumn{2}{|c|}{ PL/B } \\
\hline & Fresh $\uparrow$ & Inc. $\neq$ & Fresh & Inc. & Fresh & Inc. & Fresh & Inc. & Fresh & Inc \\
\hline & & & & & - $\%$ & al - & & & & \\
\hline \multicolumn{11}{|c|}{ th detectable $\mathrm{NO}_{9}^{-}-\mathrm{N}$} \\
\hline $\begin{array}{l}\text { Humus } \\
\text { Soil }(0-9 \mathrm{~cm}) \\
\text { Soil }(9-18 \mathrm{~cm})\end{array}$ & $\begin{array}{l}1.4 \\
0.7 \\
7.6\end{array}$ & $\begin{array}{l}2.1 \\
0.7 \\
1.4\end{array}$ & $\begin{array}{r}8 \\
33 \\
36\end{array}$ & $\begin{array}{l}10 \\
32 \\
38\end{array}$ & $\begin{array}{l}12 \\
41 \\
40\end{array}$ & $\begin{array}{l}14 \\
45 \\
43\end{array}$ & $\begin{array}{l}11 \\
37 \\
42\end{array}$ & $\begin{array}{l}12 \\
40 \\
37\end{array}$ & $\begin{array}{l}14 \\
46 \\
49\end{array}$ & $\begin{array}{l}17 \\
54 \\
47\end{array}$ \\
\hline \multicolumn{11}{|c|}{ Mean $\mathrm{NO}_{\mathrm{g}}^{-} \mathrm{N}$ concentration } \\
\hline $\begin{array}{l}\text { Humus } \\
\text { Soil }(0-9 \mathrm{~cm}) \\
\text { Soil }(9-18 \mathrm{~cm})\end{array}$ & $\begin{array}{l}0.6 \\
0.7 \\
0.6\end{array}$ & $\begin{array}{l}0.8 \\
0.9 \\
0.6\end{array}$ & $\begin{array}{l}0.8 \\
1.2 \\
1.0\end{array}$ & $\begin{array}{l}1.0 \\
1.0 \\
1.1\end{array}$ & $\begin{array}{l}1.3 \\
1.6 \\
1.4\end{array}$ & $\begin{array}{l}1.5 \\
1.7 \\
1.3\end{array}$ & $\begin{array}{l}1.1 \\
1.2 \\
1.2\end{array}$ & $\begin{array}{l}1.2 \\
1.4 \\
1.1\end{array}$ & $\begin{array}{l}1.4 \\
1.9 \\
1.6\end{array}$ & $\begin{array}{l}1.7 \\
2.0 \\
1.8\end{array}$ \\
\hline \multicolumn{11}{|c|}{ Maximum NO$-\mathrm{N}$ concentration } \\
\hline $\begin{array}{l}\text { Humus } \\
\text { Soil }(0-9 \mathrm{~cm}) \\
\text { Soil }(9-18 \mathrm{~cm})\end{array}$ & $\begin{array}{l}0.8 \\
1.3 \\
1.2\end{array}$ & $\begin{array}{l}1.0 \\
1.3 \\
1.2\end{array}$ & $\begin{array}{l}1.4 \\
2.6 \\
3.2\end{array}$ & $\begin{array}{l}3.1 \\
3.0 \\
2.8\end{array}$ & $\begin{array}{l}4.9 \\
9.6 \\
7.1\end{array}$ & $\begin{array}{l}4.3 \\
8.8 \\
7.4\end{array}$ & $\begin{array}{l}3.7 \\
2.9 \\
2.8\end{array}$ & $\begin{array}{l}2.6 \\
3.8 \\
2.4\end{array}$ & $\begin{array}{r}5.6 \\
12.4 \\
7.5\end{array}$ & $\begin{array}{l}5.1 \\
9.3 \\
8.6\end{array}$ \\
\hline
\end{tabular}

$\dagger$ Total number of samples in each treatment $=144$.

$\ddagger$ Total number of samples in each treatment $=132$.

Table 2. Humus and soil pH in the undisturbed beech forest and in the clearcut-logged and clear-cut logged and burned treatments at different biomass sampling periods.

\begin{tabular}{|c|c|c|c|c|c|}
\hline \multirow{2}{*}{$\begin{array}{l}\text { Sampling } \\
\text { period }\end{array}$} & \multirow[b]{2}{*}{ Treatment } & \multicolumn{2}{|c|}{ Humus } & \multicolumn{2}{|c|}{ Soil $(0-9 \mathrm{~cm})$} \\
\hline & & $\mathrm{H}_{2} \mathrm{O}$ & $\mathrm{CaCl}_{2}$ & $\mathrm{H}_{8} \mathrm{O}$ & $\mathrm{CaCl}_{\mathrm{g}}$ \\
\hline Preburn & $\begin{array}{l}\mathrm{F} \\
\mathrm{CL} \\
\mathrm{CL} / \mathrm{B} \\
\mathrm{PL} \\
\mathrm{PL} / \mathrm{B}\end{array}$ & $\begin{array}{l}3.4 \mathrm{a} \dagger \\
4.0 \mathrm{~b} \\
3.8 \mathrm{~b} \\
3.9 \mathrm{~b} \\
3.9 \mathrm{~b}\end{array}$ & $\begin{array}{l}2.8 \mathrm{a} \\
3.5 \mathrm{~b} \\
3.2 \mathrm{~b} \\
3.3 \mathrm{~b} \\
3.4 \mathrm{~b}\end{array}$ & $\begin{array}{l}\ddot{-} \\
= \\
-\end{array}$ & $\begin{array}{l}- \\
\ddot{.} \\
- \\
\ddot{-}\end{array}$ \\
\hline Postburn & $\begin{array}{l}\text { CL/B } \\
\mathrm{PL} / \mathrm{B}\end{array}$ & $\begin{array}{l}4.1 \mathrm{a} \\
4.4 \mathrm{a}\end{array}$ & $\begin{array}{l}3.6 \mathrm{a} \\
3.8 \mathrm{a}\end{array}$ & $\overline{-}$ & - \\
\hline $\begin{array}{l}\text { Postburn } \\
\text { (2 yr) }\end{array}$ & $\begin{array}{l}\mathrm{F} \\
\mathrm{CL} \\
\mathrm{CL} / \mathrm{B} \\
\mathrm{PL} \\
\mathrm{PL} / \mathrm{B}\end{array}$ & $\begin{array}{l}3.6 \mathrm{a} \\
4.1 \mathrm{~b} \\
4.1 \mathrm{bc} \\
4.2 \mathrm{bc} \\
4.4 \mathrm{c}\end{array}$ & $\begin{array}{l}3.1 \mathrm{a} \\
3.6 \mathrm{~b} \\
3.6 \mathrm{~b} \\
3.7 \mathrm{~b} \\
3.9 \mathrm{~b}\end{array}$ & $\begin{array}{l}4.1(0.4) \ddagger \\
4.4(0.5) \\
4.3(0.2) \\
4.3(0.4) \\
4.4(0.4)\end{array}$ & $\begin{array}{l}3.5(0.4) \\
3.8(0.4) \\
3.7(0.2) \\
3.7(0.3) \\
3.8(0.4)\end{array}$ \\
\hline
\end{tabular}

$\dagger$ Numbers within columns followed by the same letters are not significantly different at the $5 \%$ level by Duncan's New Multiple Range test for comparisons between treatments within a sampling period for the preburn and postburn sampling periods.

$\ddagger$ Data in parenthesis refers to standard deviation.

$\mathrm{NH}_{4}^{+}-\mathrm{N}$ concentrations between blocks were examined for homogeneity of variance using Bartlett's test.

Humus and soil pH were measured with a combination glass electrode using both distilled water and $0.1 M \mathrm{CaCl}_{2}$. An extractant/sample ratio of 10:1 and 2.5:1 was used for the humus and soil, respectively.

Moisture contents of fresh, incubated humus and soil samples were determined by oven-drying at $105^{\circ} \mathrm{C}$ for $24 \mathrm{~h}$ and expressed on oven-dry weight method. Forest floor temperature was determined by the sucrose inversion method (Jones and Court, 1980; Heng, 1980).

The data were analyzed using analysis of variance, Duncan's Multiple Range test, and $t$-test. These tests were performed using the Teddybear program (Wilson, 1976) on a Burroughs B6700 computer.

\section{RESULTS AND DISCUSSION}

\section{Nitrate}

No significant differences in variances were found between plots; therefore, statistical comparisons were made between data obtained in the undisturbed beech forest and from the harvested plots.

Detectable $\mathrm{NO}_{3}^{-}-\mathrm{N}$ concentrations $\left(\geqq 0.1 \mathrm{mg} \mathrm{kg}^{-1}\right.$ ) are shown in Table 1. The low detection of $\mathrm{NO}_{3}^{-}-\mathrm{N}$ could be due to $\mathrm{NO}_{3}^{-}-\mathrm{N}$ being leached from the tubes with soil moisture. Nitrate was detected more frequently in the soil than in the humus layer in all treatments. Although some $\mathrm{NO}_{3}^{-}$undoubtedly leached from the samples during moist periods, sizeable differences in $\mathrm{KCl}$ extractable $\mathrm{NO}_{3}^{-}$could still be found between treatments. The mean and maximum $\mathrm{NO}_{3}^{-}-\mathrm{N}$ concentration, and the proportion of samples with detectable $\mathrm{NO}_{3}^{-}-\mathrm{N}$ in the humus and soil generally decreased in the order:

$$
\mathrm{PL} / \mathrm{B}>\mathrm{CL} / \mathrm{B}>\mathrm{PL}>\mathrm{CL}>\text { beech forest } .
$$

Within each treatment, there were no significant differences in $\mathrm{NO}_{3}^{-}-\mathrm{N}$ concentrations between field fresh and field incubated samples of humus and soil. Probably, this reflects the high mobility of $\mathrm{NO}_{3}^{-}-\mathrm{N}$ in the soil solution, rather than a lack of incubation effect.

In the undisturbed beech forest, $\mathrm{NO}_{3}^{-}-\mathrm{N}$ was negligible or undetected in fresh and incubated humus and soil samples (Table 1). Nitrification however, appeared to be enhanced by both clearcutting and clearcutting and burning, although detectable $\mathrm{NO}_{3}^{-}-\mathrm{N}$ was generally found in less than half of all fresh and incubated humus and soil samples. Highest $\mathrm{NO}_{3}^{-}-\mathrm{N}$ was found in the burned plots within 60 to $90 \mathrm{~d}$ after burning. This was probably due to the nitrification of some of the abundant $\mathrm{NH}_{4}^{+}-\mathrm{N}$ present in the humus layer and soil during this period (Fig 1.) A significantly higher humus $\mathrm{pH}$ in burned plots (Table 2) may have promoted nitrification. Before burning, humus $\mathrm{pH}$ in the beech forest was 3.4 compared to a mean of 3.9 in the clearcut sites. Although low $\mathrm{pH}$ conditions have been reported to inhibit nitrification (Alexander, 1977), appreciable levels of $\mathrm{NO}_{3}^{-}-\mathrm{N}$ have been found in soils of pH 4.0 or less (Romell, 1932; Smith et al., 1968; Weber and Gainey, 1962). Removal of the forest canopy would eliminate inputs of water-soluble polyphenols to the humus and soil in throughfall and lit- 
Table 3. Mean forest floor temperatures recorded at Larry's Creek. $\dagger$

\begin{tabular}{|c|c|c|c|c|c|c|}
\hline \multirow[b]{2}{*}{ Sampling period } & \multicolumn{2}{|c|}{ Forested site } & \multicolumn{2}{|c|}{ Clearcut site } & \multicolumn{2}{|c|}{ Burned site } \\
\hline & $\bar{x}\left({ }^{\circ} \mathrm{C}\right)$ & CI & $\bar{x}\left({ }^{\circ} \mathrm{C}\right)$ & CI & $\bar{x}\left({ }^{\circ} \mathrm{C}\right)$ & CI \\
\hline 15 Julv 1976-17 A 197 & 6.9 & $(0.5) \ddagger$ & 7.5 & $(0.6)$ & & - \\
\hline & & & & & & -- \\
\hline 190 & 13.1 & $(0.8)$ & 15.1 & 10. & .. & -- \\
\hline & 13.3 & & 14.6 & $(0.5)$ & 15.6 & $(0.4)$ \\
\hline & 9.2 & $(0.2)$ & 9.4 & $(0.4)$ & 9.2 & $(0.4)$ \\
\hline & 6.2 & $(0.2)$ & 5.7 & (1.0) & 6.3 & $(0.7)$ \\
\hline & 5.5 & $(0.1)$ & 5.9 & (0.2) & 5.3 & $(0.4)$ \\
\hline 70 & 12.7 & (1.1) & 15.5 & (0.4) & 14.8 & (1.0) \\
\hline 1978-8 Apr. 1978 & 15.7 & (0.1) & 21.1 & (0.6) & 19.6 & $(1.2)$ \\
\hline & 13. & (0.4) & 13.8 & (0.4) & 13.9 & $(0.4)$ \\
\hline 9 July $1978-7$ Oct. 1978 & 10.1 & (0.1) & 11.1 & $(0.4)$ & 10.4 & $(0.4)$ \\
\hline
\end{tabular}

$\dagger$ Data obtained by Heng (1980) on the same plots.

$\ddagger$ Data in parenthesis refer to $95 \%$ confidence interval (CI).

terfall. The presence of tannins and other polyphenols are known to inhibit nitrification (Rice and Pancholy, 1974). Removal of organic materials from forest floor during harvesting or site preparation also reduces the capacity of the soil to retain N (Vitousek and Matson, 1984).

\section{Ammonium}

Ammonium was the dominant mineral $\mathrm{N}$ form in the humus layer and soil. Seasonal trends in fresh humus and soil were found for all treatments (Fig. 1). Peak concentrations occurred in the fall $\left(61.6 \mathrm{mg} \mathrm{kg}^{-1}\right.$ in humus, $11.5 \mathrm{mg} \mathrm{kg}^{-1}$ in soils) and spring (46.0 $\mathrm{mg}$ $\mathrm{kg}^{-1}$ in humus, $13.6 \mathrm{mg} \mathrm{kg}^{-1}$ in soil). The peak levels of $\mathrm{NH}_{4}^{+}-\mathrm{N}$ generally corresponded to periods of litterfall reported by Heng (1980) for the West Coast beech forests. The higher $\mathrm{NH}_{4}^{+}-\mathrm{N}$ levels in the spring probably reflected seasonal changes in microbial populations due to increased forest floor temperatures (Table 3 ). Heng (1980) reported high rates of $\mathrm{CO}_{2}$ evolution for these sites in the spring months. Lowest $\mathrm{NH}_{4}^{+}-\mathrm{N}$ concentrations in the humus layer $\left(17.6 \mathrm{mg} \mathrm{kg}^{-1}\right)$ were found in July when forest floor temperatures and biological activity were low. The $\mathrm{NH}_{4}^{+}-\mathrm{N}$ levels in field incubated humus and soil samples were generally higher, but followed a pattern similar to that found in the corresponding field fresh samples (Fig. 2).

The net change in $\mathrm{NH}_{4}^{+}-\mathrm{N}$ concentrations between sampling periods is a result of several processes (e.g., immobilization, leaching from the columns, in situ ammonification). In the undisturbed beech forest, increases in $\mathrm{NH}_{4}^{+}-\mathrm{N}$ occurred throughout most of the year (Fig. 3). Highest net accumulations of $\mathrm{NH}_{4}^{+}-\mathrm{N}$ (48.0 $\mathrm{mg} \mathrm{kg}^{-1}$ in humus, $10.5 \mathrm{mg} \mathrm{kg}^{-1}$ in soil) occurred in spring (Fig. 3). This is to be expected as plant uptake would be greatest in the spring, thus increasing the relative differences in $\mathrm{NH}_{4}^{+}-\mathrm{N}$ levels between the fresh and corresponding incubated samples. Low $\mathrm{NH}_{4}^{+}-\mathrm{N}$ levels occurred in the winter months in the humus and soil, probably due to low soil temperature (Powers, 1980), microbial immobilization, denitrification, leaching, reducing litter input, or to a combination of these factors.

Nitrogen mineralization was not monitored in the clearcut plots until just before burning. Immediately after clearcutting, ammonification in the humus layer
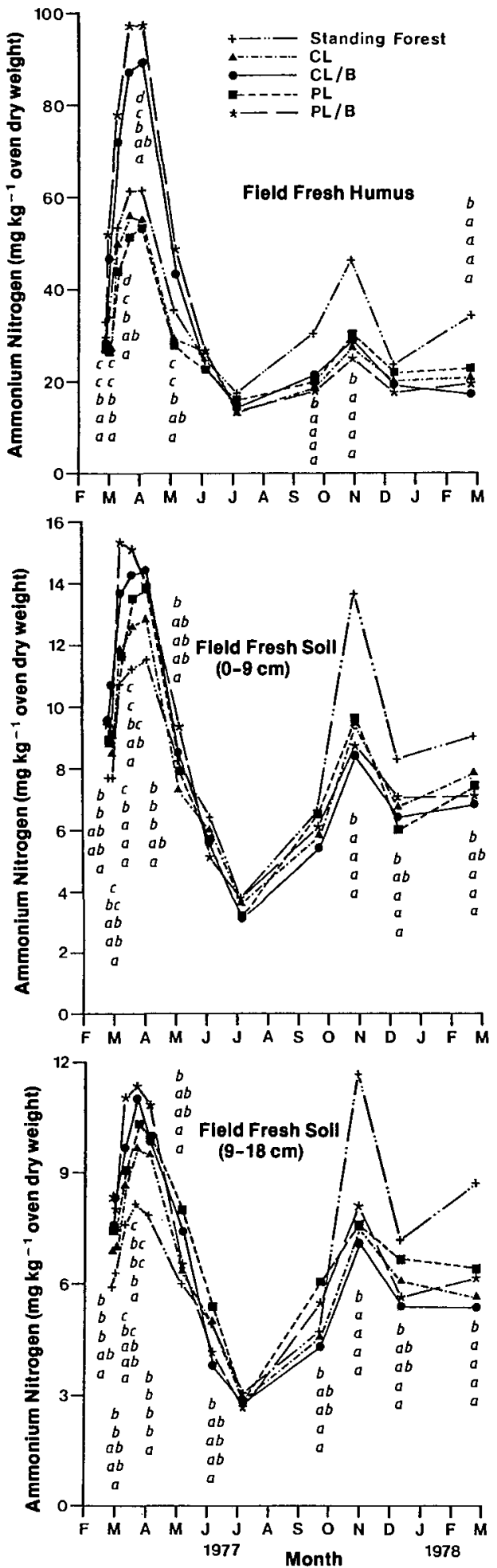

Fig. 1. Seasonal pattern in mean $\mathrm{NH}_{4}^{+}-\mathbf{N}$ concentration in field fresh humus and fresh soil $(0-9,9-18 \mathrm{~cm})$ in the standing forest and in the clearcut logged and clearcut logged/burned plots (small letters at each sampling period indicate results from Duncan's Multiple Range Tests; see Table 2 for abbreviations).

and soil would have increased above that in the undisturbed forest (Arefyeva and Kolesnikov, 1964). After the initiation of sampling, the general pattern of ammonification in the fresh and incubated humus and 

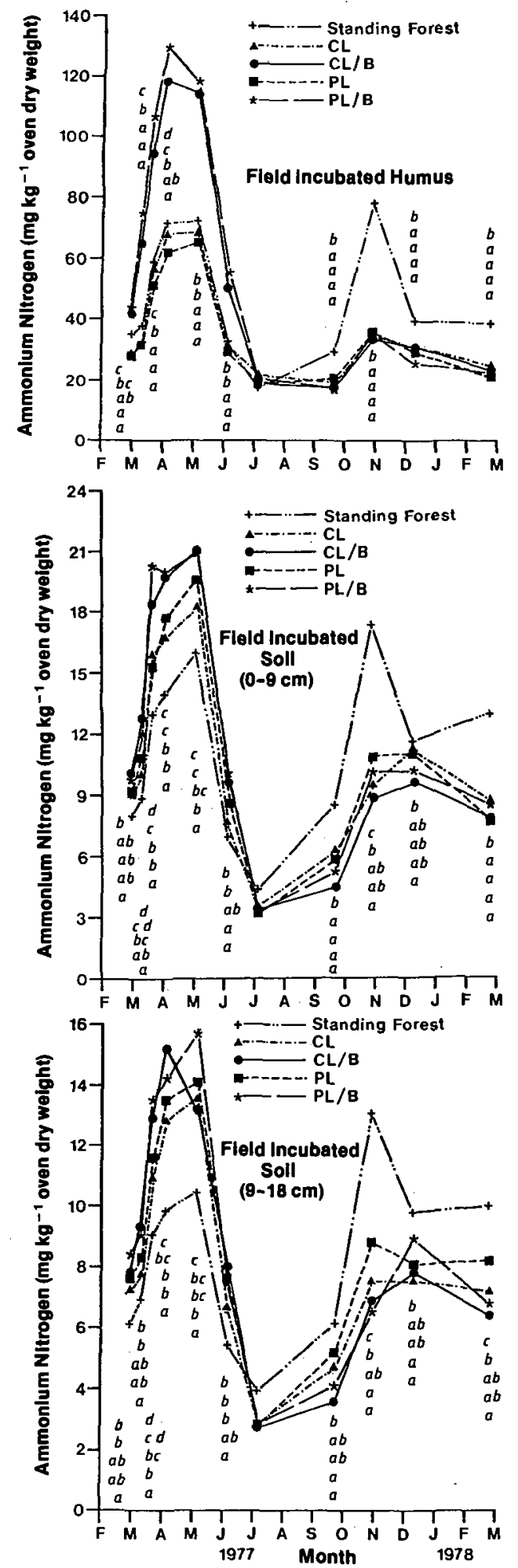

Fig. 2. Seasonal pattern in mean $\mathrm{NH}_{4}^{+}-\mathrm{N}$ concentration in field incubated humus and soil $(0-9,9-18 \mathrm{~cm})$ in the standing forest and in the clearcut logged and clearcut logged/burned plots (for explanation of abbreviations see Fig. 1).

soil samples in all clearcut plots was similar to that found in the undisturbed beech forest (Fig. 1 and 2). However, important differences in the levels of $\mathrm{NH}_{4}^{+}-\mathrm{N}$ were found. In the CL and PL treated plots, $\mathrm{NH}_{4}^{+}-\mathrm{N}$ concentrations in the fresh and incubated hu-
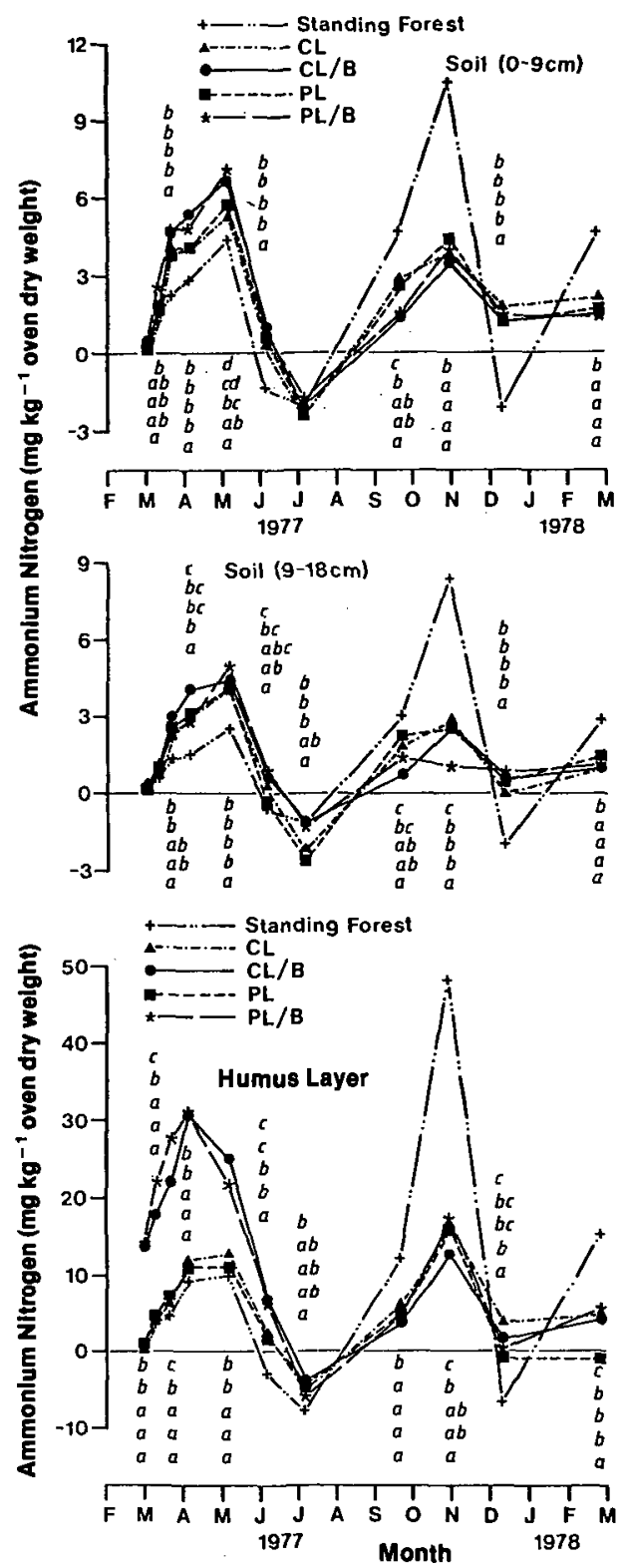

Fig. 3. Seasonal pattern in mean net $\mathrm{NH}_{\mathbf{4}}^{+} \mathbf{- N}$ concentration in humus and soil (0-9, 9-18 cm) in the standing forest and in the clearcut logged/burned plots (for explanation of abbreviations see Fig. 1).

mus samples were lower than those found in the undisturbed beech forest throughout the study. The relative differences in humus $\mathrm{NH}_{4}^{+}-\mathrm{N}$ concentrations between those in the undisturbed beech forest and those in the CL and PL treated plots generally increased with time. Many of the differences were statistically significant. A similar effect was found in the soil, although the soil $\mathrm{NH}_{4}^{+}-\mathrm{N}$ levels were initially higher in the CL and PL treated plots (Fig. 1 and 2).

Net accumulations of $\mathrm{NH}_{4}^{+}-\mathrm{N}$ in the humus layer in the $\mathrm{Cl}$ and $\mathrm{PL}$ treated plots during the fall months were not significantly different from those in the undisturbed beech forest (Fig. 3). In the soil, these differences generally were statistically significant with higher $\mathrm{NH}_{4}^{+}-\mathrm{N}$ levels in the clearcut plots. This probably reflected a continued decrease in the quantity of easily mineralizable $\mathrm{N}$ substances in the clearcut plots 
or increased amount of leaching from columns in the clearcut plots.

Increases in soil $\mathrm{NH}_{4}^{+}-\mathrm{N}$ concentrations after burning have been observed in other studies (Christensen, 1973; DeBano et al., 1979; Dunn et al., 1979). In the present study, prescribed burning had a short-term but significant impact on $\mathrm{NH}_{4}^{+}-\mathrm{N}$ concentrations in the humus layer, but little measurable effect on soil $\mathrm{NH}_{4}^{+}-\mathrm{N}$ concentrations (Fig. 1). The minimal effect on soil $\mathrm{NH}_{4}^{+}-\mathrm{N}$ levels was probably because both burning treatments were of light to moderate intensity (unpublished data).

Ammonium $\mathrm{N}$ concentrations in the fresh and incubated soil samples in the CL/B and PL/B treated plots generally were higher than those in the CL and Pl treated plots for approximately $60 \mathrm{~d}$ after burning (Fig. 1 and 2). Not all of the differences were statistically significant.

Large increases in $\mathrm{NH}_{4}^{+}-\mathrm{N}$ concentrations were found in fresh and incubated humus samples 3-d after burning (Fig. 1 and 2). This could have resulted from direct inputs from the ash layer, as $\mathrm{NH}_{4}^{+}-\mathrm{N}$ has been reported to be a major $\mathrm{N}$ component in ash (Christensen, 1973). The thermal decomposition of amino components in the humus is another possibility (Russell et al., 1974). Ammonium $\mathrm{N}$ concentrations continued to increase, reaching maximum values in the fresh humus from $21-\mathrm{d}\left(\mathrm{CL} / \mathrm{B}=82.7 \mathrm{mg} \mathrm{kg}^{-1}, \mathrm{PL} / \mathrm{B}\right.$ $\left.=97.5 \mathrm{mg} \mathrm{kg}^{-1}\right)$ to $35-\mathrm{d}\left(\mathrm{CL} / \mathrm{B}=89.4 \mathrm{mg} \mathrm{kg}^{-1}\right)$ after burning (Fig. 2). For the incubated humus samples, the maximum values $\left(\mathrm{CL} / \mathrm{B}=118 \mathrm{mg} \mathrm{kg}^{-1}, \mathrm{PL} / \mathrm{B}=\right.$ $129 \mathrm{mg} \mathrm{kg}^{-1}$ ) were found at $35 \mathrm{~d}$ after burning (Fig. 2). Throughout these $35 \mathrm{~d}, \mathrm{NH}_{4}^{+}-\mathrm{N}$ concentrations in the fresh and incubated humus samples in the CL/B and PL/B treated plots were significantly higher that those found in the beech forest and the $\mathrm{CL}$ and PL treated plots.

The continued increase in $\mathrm{NH}_{4}^{+}-\mathrm{N}$ concentrations for the first 35-d after burning suggests a rapid increase in the population of ammonifying organisms, possibly due to the elimination of other competing organisms for the same substrate. Burning has been shown to favor bacteria rather than fungi (Jones and Richards, $1977 ; 1978)$. Miller et al. (1955) reported that bacterial populations reached a peak within a month after light to moderate burns in New Zealand hill country, and then reverted to their initial preburn levels. A similar effect probably occurred at Larry's Creek.

Humus $\mathrm{NH}_{4}^{+}-\mathrm{N}$ concentrations returned close to those found in the CL and PL treated plots in $<120$ d after burning (Fig. 1).

Results from regression analysis indicated no significant correlations between $\mathrm{NH}_{4}^{+}-\mathrm{N}$ concentrations and moisture content in fresh humus and soil samples. No regression analysis was done for temperature. However, multiple linear regression analysis by Heng (1980) revealed no significant relationship between $\mathrm{NH}_{4}^{+}-\mathrm{N}$ concentration and both moisture content and forest floor temperatures in both hard beech and radiata pine forests. The spatial variation in such factors as litterfall, competition for the $\mathrm{NH}_{4}^{+}-\mathrm{N}$ ion, total $\mathrm{N}$, substrate quality, and polyphenol content could mask or reduce the ability to measure effects of temperature and moisture on $\mathrm{NH}_{4}^{+}-\mathrm{N}$ dynamics.

\section{CONCLUSIONS}

Results presented showed that $\mathrm{NH}_{4}^{+}-\mathrm{N}$ was the dominant inorganic $\mathrm{N}$ form retained in the humus layer and soil. The $\mathrm{NH}_{4}^{+}-\mathrm{N}$ levels increased immediately after burning and were affected by site disturbance (e.g., clearcutting). Burning substantially increased $\mathrm{NH}_{4}^{+}-\mathrm{N}$ levels in the humus and to a lesser extent in the soil for approximately $120 \mathrm{~d}$ after burning. Trends of extractable $\mathrm{NO}_{3}^{-}-\mathrm{N}$ concentrations reflected those of $\mathrm{NH}_{4}^{+}-\mathrm{N}$ in the topsoil. The enhanced $\mathrm{NH}_{4}^{+}-\mathrm{N}$ production is likely to effect increases in $\mathrm{NO}_{3}^{-}-\mathrm{N}$ in the soil solution which may lead to increased fluxes of $\mathrm{NO}_{3}^{-}-\mathrm{N}$ through the soil profile in the field. This aspect remains to be investigated.

\section{ACKNOWLEDGMENTS}

We wish to thank the Forest Research Institute, New Zealand Forest Service and the Lincoln College Research Committee for providing research funds and assistance and to Drs. D. J. Mead and G. M. Will for their encouragement and assistance.

\section{REFERENCES}

Adams, J.A., and G. Mew. 1975. Soils of the Inangahua Depression, South Island, New Zealand. Part II. Soil chemistry and forestry appraisal. N.Z. Soil Survey Rep. 17:39-78.

Alexander, M. 1977. Introduction to soil microbiology. John Wiley and Sons Inc., New York.

Aref yeva, Z.N., and B.P. Kolesnikov. 1964. Dynamics of ammonia and nitrate nitrogen in forest soils of the Transurals at high and low temperatures. Soviet Soil Sci. (Engl. Transl.) 3:246-260.

Christensen N.L. 1973. Fire and nitrogen cycle in California chaparral. Science 181:66-67.

DeBano, L.F., G.E. Eberlein, and P.H. Dunn. 1979. Effects of burning on chaparral soils. I. Soil nitrogen. Soil Sci. Soc. Am. J. 43:504 509.

Dunn, P.H., L.F. DeBano, and G.E. Eberlein. 1979. Effects of burning on chapparal soils. II. Soil microbes and nitrogen mineralization. Soil Sci. Soc. Am. J. 43:509-514.

Ellis, R.C. 1974. The seasonal pattern of nitrogen and carbon mineralization in forest and pasture soils in southern Ontario. Can. J. Soil Sci. 54:15-28.

Grasshoff, K. 1969. A simultaneous multiple channel system for nutrient analysis in seawater with analog and digital data record. p. 133-150. In Advances in automated analysis. Technicon International Congress 1969, vol. II. Industrial Analysis, New York.

Heng, S. 1980. The addition, decomposition and accumulation of organic matter in some native Nothofagus spp. forests and radiata plantations in the South Island of New Zealand, Ph.D. diss., Univ. of Canterbury, New Zealand.

Jones, R.J.A., and M.N. Court, 1980. The measurement of mean temperatures in plant and soil studies by the sucrose inversion method. Plant Soil 54:15-31.

Jones, J.M., and B.N. Richards. 1977. Changes in the microbiology of eucalypt forest soils following reafforestation with exotic pines. Aust. For. Res. 7:229-240.

Jones, J.M., and B.N. Richards. 1978. Fungal development and the transformation of N-labelled amino- and ammonium-nitrogen in forest soils under several management regimes. Soil Biol. Biochem. 10:161-168.

Likens, G.E., F.H. Bormann, N.M. Johnson, D.W. Fisher, and R.S. Pierce. 1970. Effects of forest cutting and herbicide treatment on nutrient budgets in the Hubbard Brook watershed ecosystem. Ecol. Monogr. 40:23-47.

Miller, R.B., J.D. Stout, and K.E. Lee. 1955. Biological and chemical changes following scrub burning on a New Zealand soil. N.Z. J. Sci. Tech. 37:190-313.

Powers, R.F. 1980. Mineralizable soil nitrogen as an index of nitrogen availability to forest trees. Soil Sci. Soc. Am. Proc. 44:13141320 .

Rice, E.L., and S.K. Pancholy. 1974. Inhibition of nitrification by climax ecosystems. III. Inhibitors other than tannins. Am. J. Bot. 61:1095-1103.

Romell, L.G. 1932. Mull and duff as biotic equilibria. Soil Sci. 34:161-168. 
Russell, J.D., A.R. Fraser, J.R. Watson, and J.W. Parsons. 1974. Thermal decomposition of protein in soil organic matter. Geoderma 11:63-66.

Smith, W., F.H. Bormann, and G.E. Likens. 1968. Response of chemoautotrophic nitrifiers to forest cutting. Soil Sci. 106:471473.

Vitousek, P.M., and P.A. Matson. 1984. Mechanism of nitrogen retention in forest ecosystems: A field experiment. Science 225:5152.

Vitousek, P.M., J.R. Gosz, C.C. Grier, J.M. Melillo, W.A. Reiners, and R.L. Todd. 1979. Nitrate losses from disturbed ecosystems Science 204:469-474.

Weatherburn, M.W. 1967. Phenol-hypochlorite reaction for determination of ammonia. Anal. Chem. 39:971-974.

Weber, D.F., and P.L. Gainey. 1962. Relative sensitivity of nitrifying organisms to hydrogen ions in soils and in solutions. Soil Sci. 94:138-145.

Wilson, J.B. 1976. Teddybear statistical program. Tech. Rep. T5, 2nd ed. University of Otago Computing Center, Dunedin, New Zealand. 